UCRL-JC-127180

PREPRINT

\title{
Ultrahigh Carbon Steels, Damascus Steels, and Superplasticity
}

\author{
O. D. Sherby \\ J. Wadsworth
}

This paper was prepared for submittal to the 9th International Metallurgical and Materials Congress

Istanbul, Turkey

June 11-15, 1997

\section{April 1997}

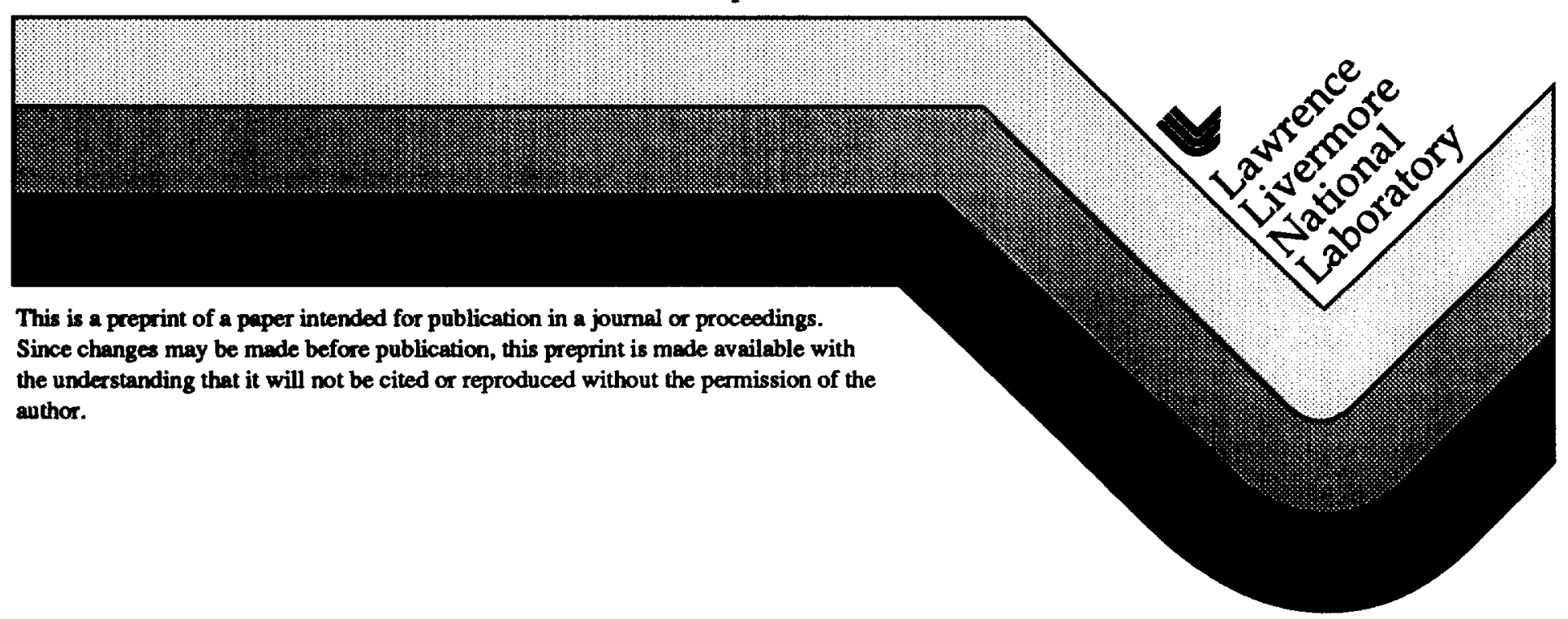




\section{DISCLAIMER}

This document was prepared as an account of work sponsored by an agency of the United States Government. Neither the United States Government nor the University of California nor any of their employees, makes any warranty, express or implied, or assumes any legal liability or responsibility for the accuracy, completeness, or usefulness of any information, apparatus, product, or process disclosed, or represents that its use would not infringe privately owned rights. Reference herein to any specific commercial products, process, or service by trade name, trademark, manufacturer, or otherwise, does not necessarily constitute or imply its endorsement, recommendation, or favoring by the United States Government or the University of California. The views and opinions of authors expressed herein do not necessarily state or reflect those of the United States Government or the University of Californiz, and shall not be used for advertising or product endorsement purposes. 


\title{
ULTRAHIGH CARBON STEELS, DAMASCUS STEELS, AND SUPERPLASTICITY
}

\author{
Oleg D. Sherby* and Jeffrey Wadsworth** \\ *Professor Emeritus, Department of Materials Science and Engineering, Stanford \\ University, Stanford, CA 94305, USA \\ **Deputy Director for Science and Technology, Lawrence Livermore National Laboratory; \\ Livermore, CA 94551, USA
}

\begin{abstract}
The processing and mechanical properties of ultrahigh carbon steels (UHCSs) have been studied at Stanford University over the past twenty years. These studies have shown that such steels ( 1 to $2.1 \% \mathrm{C}$ ) can be made superplastic at elevated temperature and can have remarkable mechanical properties at room temperature. It was the investigation of these UHCSs that eventually brought us to study the myths, magic, and metallurgy of ancient Damascus steels, which in fact, were also ultrahigh carbon steels. These steels were made in India as castings, known as wootz, possibly as far back as the time of Alexander the Great. The best swords are believed to have been forged in Persia from Indian wootz. This paper centers on recent work on superplastic UHCSs and on their relation to Damascus steels.
\end{abstract}

Keyword Words: ultrahigh carbon steels, superplasticity, strength.

\section{INTRODUCTION}

This paper centers on the mechanical behavior of ultrahigh carbon steels (1.0 to $2.1 \% \mathrm{C}$ ). These steels, now designated as UHCSs, have been viewed for most of this century as belonging in the "no man's land of carbon steels" being sandwiched between the extensively-utilized high carbon steels $(0.6$ to $1.0 \% \mathrm{C})$ and the mass-produced cast irons $(2.1$ to $4.3 \% \mathrm{C})$. This is depicted in Fig. 1 which illustrates a historical version of the most famous phase diagram, the binary Fe-C system. It took many years to complete this diagram beginning with the work of Tschernov of Russia (1868), followed by Sauveur of the United States (1896), by Roberts-Austen of England (1897), by Roozeboom of Holland (1900), and completed by Honda of Japan (1920). Even then, the E point (the maximum solubility of carbon in austenite) was erroneously labeled at $1.7 \% \mathrm{C}$ and not rectified until 1948 to its correct position at $2.1 \% \mathrm{C}$. Beyond $4.3 \% \mathrm{C}$ (in the diagram of Fig. 1), is the iron carbide region since the majority of the structure consists of iron carbide ( 65 to $100 \%$ from 4.3 to $6.67 \% \mathrm{C}$ ). The specific discoveries on the $\mathrm{Fe}-\mathrm{C}$ phase diagram are: Tchernoff established the $A_{1}$ transformation line at $723^{\circ} \mathrm{C}$, Sauveur confirmed Tchernoff's finding and established the ferrite-austenite region, Roberts-Austen established the austenite-cementite boundary and the variation of the melting point of iron with carbon additions, Roozeboom established the austenite-liquid boundary from thermodynamic reasoning, and Honda put all the knowledge gained (including the delta ferrite-austeniteliquid range) into a resemblance of the present phase diagram.

Ultrahigh carbon steels' position in the "no man's land of carbon steels" is because UHCSs have been considered to be brittle at room temperature and thus have been 


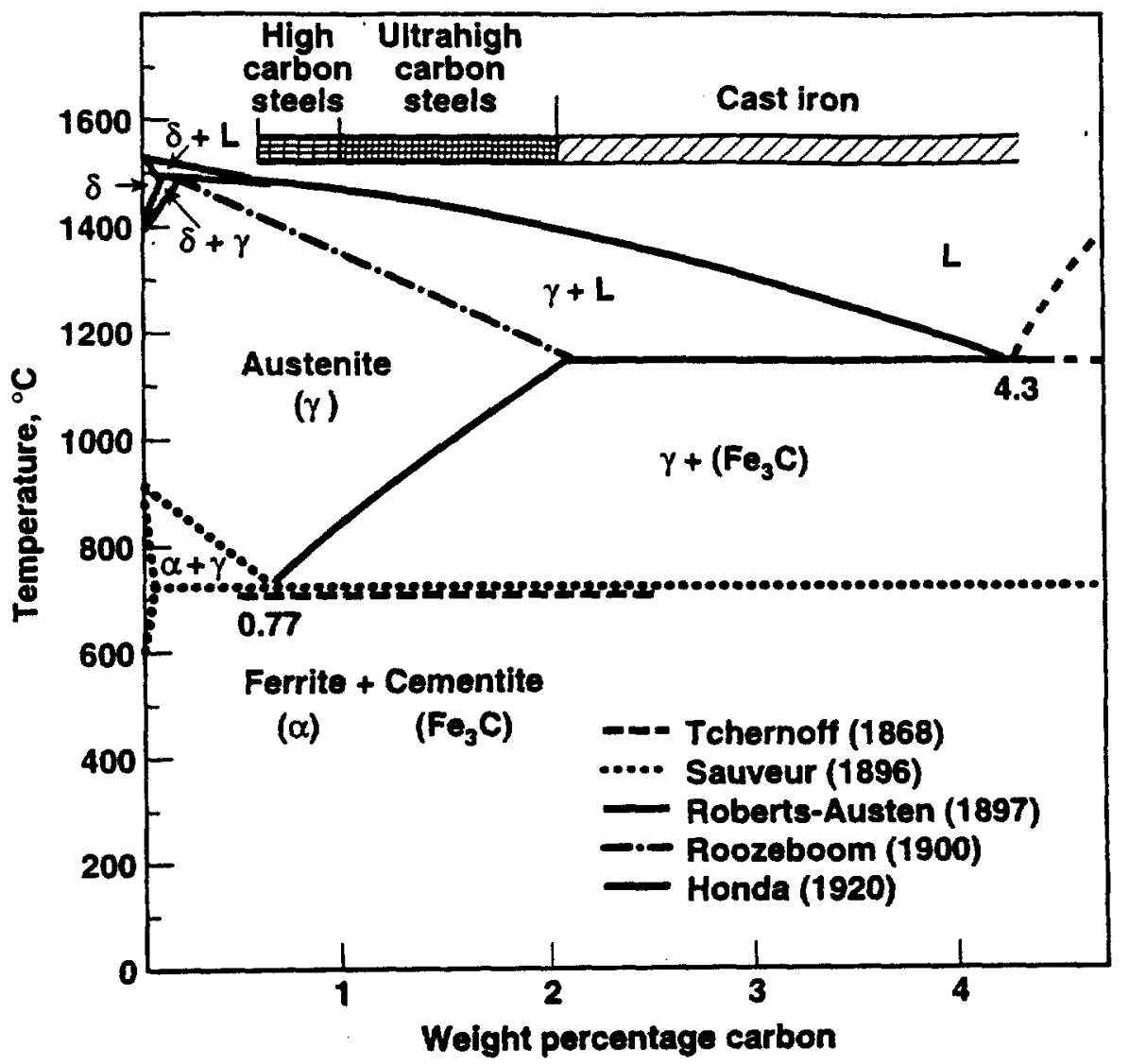

Figure 1. Historical description of the Fe-C phase diagram.

generally ignored commercially. The origin of this belief can be traced to the classic work of Howe, published in 1891 [1], in which the tensile ductility of steel was studied as a function of carbon content. A key figure from this study is shown in Fig. 2, in which tensile elongation is plotted as a function of carbon content. The tensile ductility decreases dramatically with increasing carbon content and becomes roughly constant, at 2 to $3 \%$, in the region of UHCS. The curve drawn in the figure is that given by Howe. This trend has been accepted historically and has been reproduced in many publications [2-4] since Howe's compilation. The primary reason for the low ductility in these UHCSs is the result of the formation of a continuous, thick, network of brittle iron carbide that forms in high carbon steels upon cooling from high temperature to intermediate temperature (for example, from $1000^{\circ} \mathrm{C}$ to $723^{\circ} \mathrm{C}$ for a Fe-1.6\% C alloy). An example is shown in Fig. 3 of such an iron carbide network for a $1.6 \% \mathrm{C}$ steel. These thick, continuous, networks are locations at which cracks can initiate because iron carbide is brittle at room temperature and cracks within it will readily propagate under stress causing premature failure in the steel.

At Stanford University and at the Lawrence Livermore National Laboratory, procedures have been developed to eliminate the continuous carbide network in UHCS. The result is that relatively-homogeneous structures containing fine, equiaxed ferrite grains and fine, uniformly-distributed, spheroidized carbides are readily achieved. The range in tensile ductilities for UHCS containing $1.8 \% \mathrm{C}$ is shown in Fig. 2; the wide range of values shown (from 2 to $25 \%$ ) reflects different morphologies and strengths produced by various routes [5]. 
The purpose of this paper is to illustrate the excellent properties that can be achieved in UHCSs when processed by novel procedures to obtain fine structures. In the first section, emphasis will be placed on the superplastic properties obtained, with special attention on the role of dilute alloy additions. In the second section, the low temperature mechanical properties will be reviewed with emphasis placed on the effect of heat treatment on the resulting structure-property relations. In the third section of the paper, the relation between

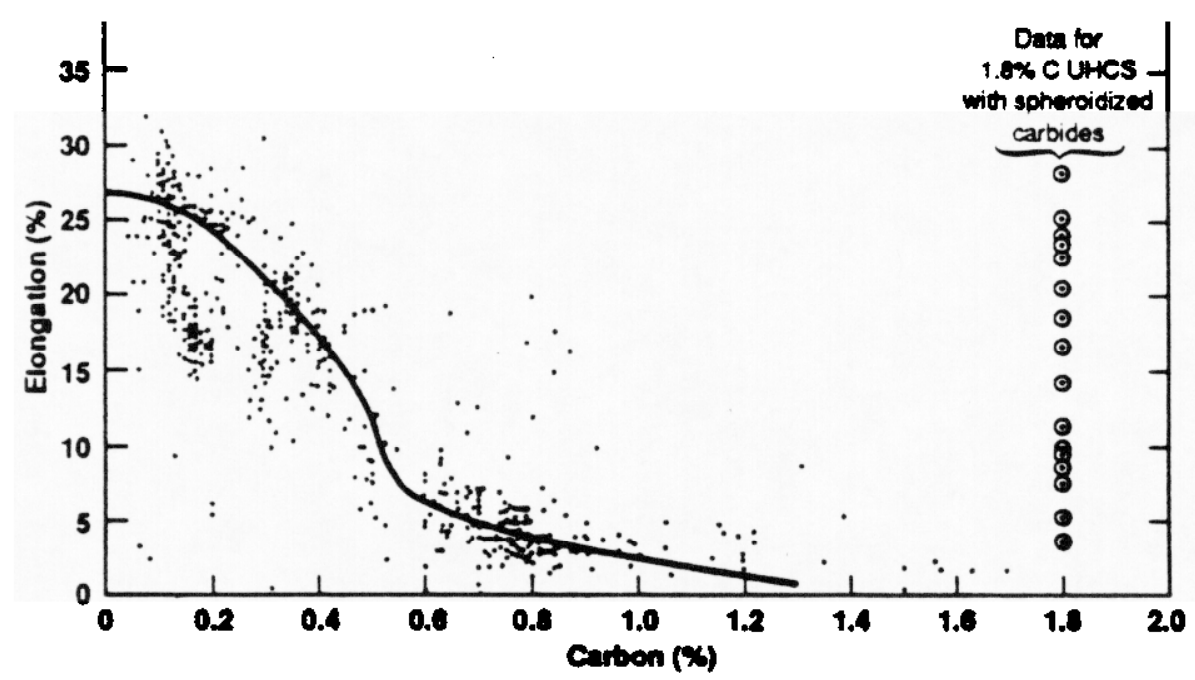

Figure 2. Historical data for the tensile elongation for steel at room temperature dramatically decreases as the carbon increases. (Reproduced from a book by the American metallurgist, Henry Howe, in 1891). Modern UHCSs can have far greater tensile elongations as shown by the data for a $1.8 \% \mathrm{C}$ UHCS.

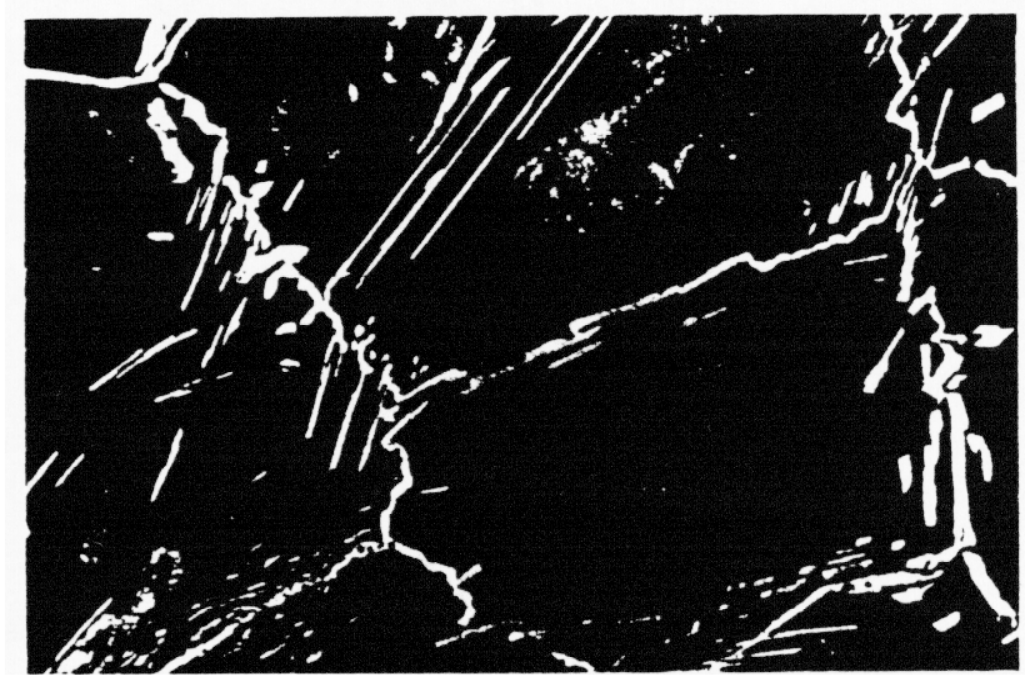

Figure 3. Micrograph of a modern ultrahigh carbon steel clearly showing a cementite network. The background structure is pearlite, i.e., alternating layers of essentially pure iron and iron carbide. (Magnification about 200 diameters.) 
the fine-grained UHCS and Damascus steels of ancient times will be covered. The interconnection has to do with the important influence of the carbide network (Fig. 2) and the associated processing which results in outstanding properties of ancient Damascus steel weapons. Some of the myths, magic, and metallurgy of Damascus steel will be covered.

\section{SUPERPLASTICITY IN ULTRAHIGH CARBON STEELS}

Twenty years ago, at Stanford University, we were interested in the relatively new field of superplasticity, i.e. the condition in which certain crystalline materials can undergo very large tensile strains of up to $1000 \%$ and more. Superplasticity occurs at high temperatures and can revolutionize the manufacturing industry because superplastic materials can be formed into complex shapes. Superplastic forming can thus reduce or eliminate many of the welding, cutting, machining, and grinding steps that account for over a third of the cost of making most structural steel components. We knew that there were two main attributes required to make a metallic material superplastic. First, the material had to be fine-grained, and second, it had to have to have two phases in order to keep the grains fine at high temperature. The existence of fine grains permits deformation by a grain boundary sliding process, which gives the material a viscous-like property (the strain-rate sensitivity is high) and superplastic characteristics are achieved.

It was decided, in 1973, that it was possible to achieve this condition in a steel containing a very high carbon content. By breaking up the continuous iron carbide network at high temperature, it would result in a more forgiving, i.e. more ductile, material. And, contrary to popular belief, we knew that iron carbide is not brittle at intermediate and high temperatures. A network-free material was developed by continuously mechanically working the UHCSs $(1.3 \%, 1.6 \%$ and $1.9 \% \mathrm{C})$ as they were cooled from a white hot temperature $\left(1200^{\circ} \mathrm{C}\right)$. This mechanical working (by either rolling or forging) broke up the iron carbide networks as they were first forming during cooling, i.e. at a point at which they were still thin and not fully continuous. In this way, the iron carbide that formed upon cooling never had a chance to grow and create the thick networks normally associated with ultrahigh carbon steels. Examples of the fine microstructures developed in a $1.5 \% \mathrm{C}$ steel, taken by high magnification transmission electron microscopy, are shown in Fig. 4. The light-colored grains are iron and are sub-micron size, and the dark particles are iron carbide. This material is superplastic at high temperature and, of equal importance, is strong and ductile at room temperature. A patent was awarded [6] for the processing procedures in the development of such microstructures in UHCS. An example of a superplastically stretched UHCS sample is shown in Fig. 5, in which an elongation of over $1000 \%$ was achieved at $750^{\circ} \mathrm{C}$ with no evidence of imminent failure. The strain rate was $200 \%$ per minute.

The initial studies on superplasticity were essentially on plain carbon UHCS. Various thermomechanical processes were used including hot and warm working (HWW), isothermal warm working (IWW), divorced eutectoid transformation (DET) and divorced eutectoid transformation with associated deformation (DETWAD) $[7,8]$. Kayali, et al [9] also showed that a thermal cycling heat treatment of cast UHCS could lead to a fine structure and superplasticity.

Composition changes to enhance superplastic behavior of UHCS were carried out including small additions of chromium, vanadium, molybdenum, tungsten, and nickel [1013]. It is worth noting that, in an attempt to study the superplastic behavior of plain carbon UHCS, in a more scientific and fundamental manner, an attempt was made to study high purity Fe-C alloys. Walser, Kayali, and Sherby $[14,15]$ made the unexpected discovery 
A

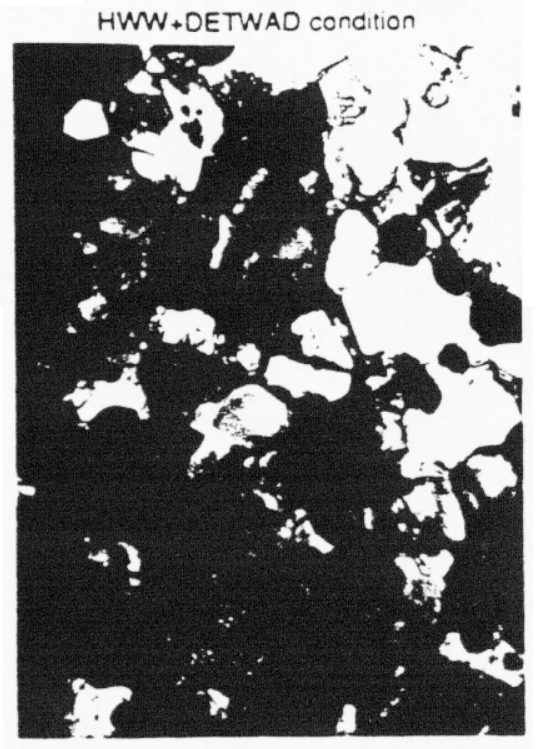

B

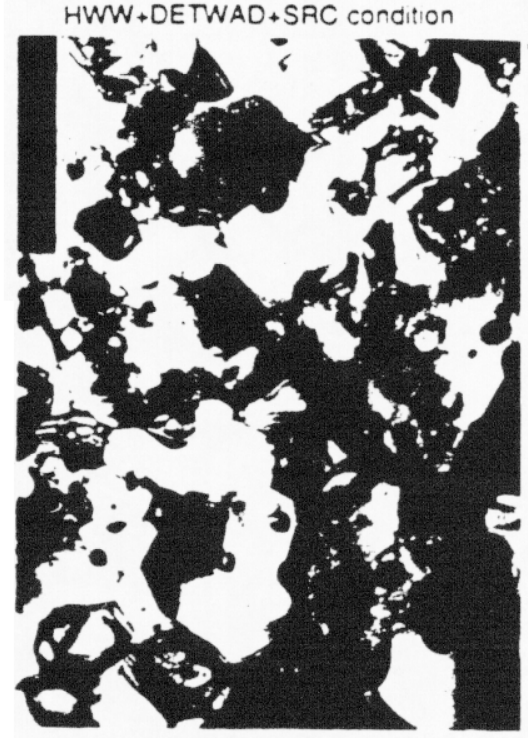

$1 \mu \mathrm{m}$

Figure 4. Photomicrographs of a 1.5\%C UHCS material processed to obtain an ultrafine grain size. The photo micrograph on the left is in the as-processed condition and the photo micrograph on the right is after deformation of the material at $700^{\circ} \mathrm{C}$.

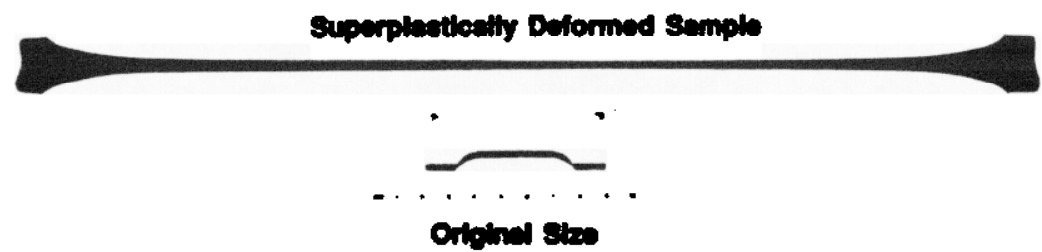

Figure 5. An example of superplastic behavior in an ultrahigh carbon steel containing about 1.8 percent $C$; an elongation of over 1,000 percent was achieved with no evidence of imminent failure. 
that the high purity $\mathrm{Fe}-\mathrm{C}$ alloys $(1.6 \%$ and $1.9 \% \mathrm{C})$ could not be made superplastic. As shown in Fig. 6 , the stress exponent value, $n$, (the slope of the curve) for the pure $1.6 \%$ $C$ alloy was high $(n=8)$, that is, the strain-rate sensitivity exponent was low, about 0.15 . The accompanying ductility was normal for a non-superplastic ductile metal (50 to 100\% elongation) [14]. Electron and optical microscopy revealed that the pure ultrahigh carbon iron alloys could not be made fine-grained. These results indicate the importance of the

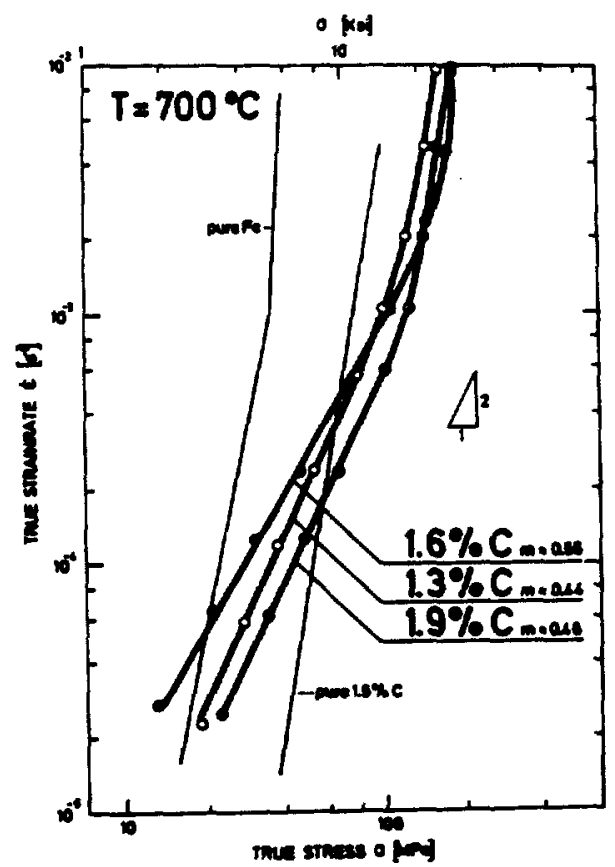

Figure 6. Comparison of the creep properties of UHCSs with pure iron and with a pure $\mathrm{Fe}-1.6 \% \mathrm{C}$ alloy.

normal additives in steel (such as $\mathrm{Mn}$ and $\mathrm{Si}$ ) in retarding and controlling the growth of grains and cementite particles.

Extensive research was done on the influence of silicon and aluminum in enhancing the superplastic behavior of UHCS. The basis for selecting these two elements was as follows. The maximum temperature where superplasticity in UHCSs can be observed is at the $\mathrm{A}_{1}$ transformation temperature $\left(723^{\circ} \mathrm{C}\right.$ for plain carbon steel; see Fig. 1). Above this temperature, austenite forms and a large fraction of the carbides dissolve so the austenite grains can then grow readily and superplasticity will be inhibited. Alloying elements such as aluminum and silicon stabilize the ferrite phase thus increasing the transformation temperature. For example, for a $1.25 \% \mathrm{C} \mathrm{UHCS}$, the $\mathrm{A}_{1}$ temperature is increased to $850^{\circ} \mathrm{C}$ with 4 wt\% Si and to $950^{\circ} \mathrm{C}$ with $10 \mathrm{wt} \% \mathrm{Al}$. Both UHCS-Si and UHCS-Al alloys were successfully processed to achieve fine-grains, and patents were issued for their microstructure-superplastic property relations $[16,17]$. The UHCS-Al alloys with a high concentration of aluminum ( 7 to $10 \% \mathrm{Al}$ ) showed the most promising high temperature properties [18].

The UHCS-high Al alloys were found to be oxidation resistant, with virtually no oxide scale formation even after exposure at $1200^{\circ} \mathrm{C}$ for long periods of time. Furthermore, since the activity of carbon in iron is reduced to zero when the aluminum content is at $10 \%$, little or no decarburization is observed with the UHCS-high Al alloys. It was not possible 
to achieve the same fine grain sizes as obtained with the lower aluminum content UHCS alloys (about $2 \mu \mathrm{m}$ ). Typically the grain sizes in the lower aluminum content UHCS were in the range from 5 to $10 \mu \mathrm{m}$. A sub-micron grain size material was obtained, however, by a powder metallurgy-mechanical attrition route [19]. Superplastic behavior was observed with the relatively coarse-grained UHCS-high aluminum alloys. Several rather remarkable attributes were noted in these UHCSs and are summarized as follows:

- The strain-rate sensitivity exponent approached unity $(m=1)$ at high temperatures and low strain rates for a 10Al-1.2C UHCS material [20]. That is, the material behaved like an ideal viscous fluid. The results are explained by a modified version of the grain boundary sliding model of Ball and Hutchinson [21]. Fukuyo, et al [20] showed that when grain boundary sliding is accommodated by solute-drag-diffusion-controlled dislocation motion, no dislocation pile-up occurs, and the strain rate becomes a linear function of the stress, i.e. $m=1$. The measured activation energy for superplastic flow of the UHCS-10Al material $(200 \mathrm{~kJ} / \mathrm{mole})$ was in agreement with the model since it equaled the activation energy for diffusion of aluminum in iron.

- Since the high Al UHCS alloys were behaving like Class I solid solution alloys (that is, solute drag of dislocations is the rate-controlling process), it was predicted that a strain rate sensitivity exponent equal to $\mathrm{m}=0.33$ would be observed at high strain rates. Such a respectably high strain rate sensitivity leads to quite high elongations, 200 to $300 \%$, and has been termed as "quasi-superplastic" behavior (i.e. resembling superplasticity or being superplastic-like) [22]. This behavior is shown in Fig. 7 where the flow stress is plotted as a function of the strain rate for three UHCSs containing 7 to $10 \%$ aluminum. Thus, at high strain rates, a strain rate sensitivity exponent of about 0.33 was observed. The ratecontrolling process was solute-drag controlled dislocation creep. An elongation to failure of $500 \%$ was achieved with the UHCS $-7.5 \% \mathrm{Al}-5 \% \mathrm{Cr}-1.2 \% \mathrm{C}$ material tested at $950^{\circ} \mathrm{C}$ and at a strain of $3 \%$ per second. At low strain rates, a strain-rate sensitivity exponent approaching unity was observed. In this case, the mechanism is that of grain boundary sliding accommodated by solute-drag dislocation creep.

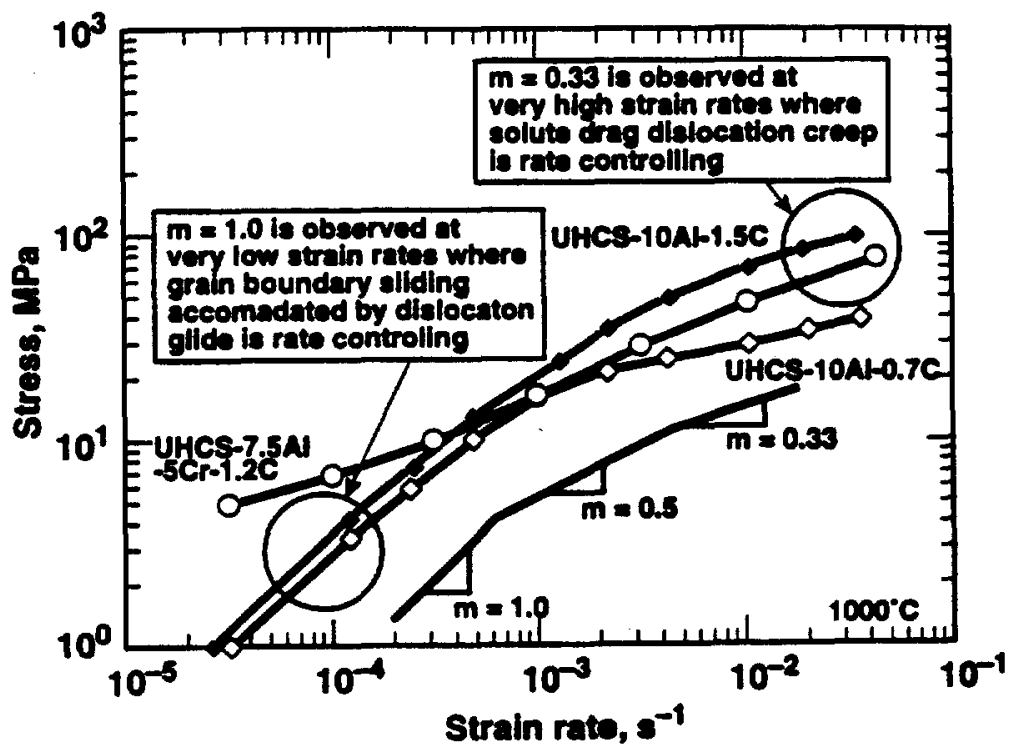

Figure 7. Quasi-superplasticity $(m=0.33)$ and ideal grain-boundary sliding $(m=1.0)$ are observed in UHCS-high aluminum alloys. 
- An example of a superplastically formed part made from a UHCS-high Al material is shown in Fig. 8. The ring component was fabricated from a UHCS-9.3Al-1.23 C at $950^{\circ} \mathrm{C}$ in air [23]. The ring, which is approximately $25 \mathrm{~cm}$ in diameter, was superplastically formed in five minutes. Commercialization of this product was intended by Sulzer Brothers of Winterthur, Switzerland, but the project was abandoned because no steel producer was prepared to make the fine-grained UHCS-high Al material. The bevel gear shown in the figure was forged at a conventional forging rate at $650^{\circ} \mathrm{C}$, and was made from an unalloyed UHCS-1.25 C material. Both components were formed close to net shape and illustrate the excellent die-fill characteristics of fine-grained UHCS.

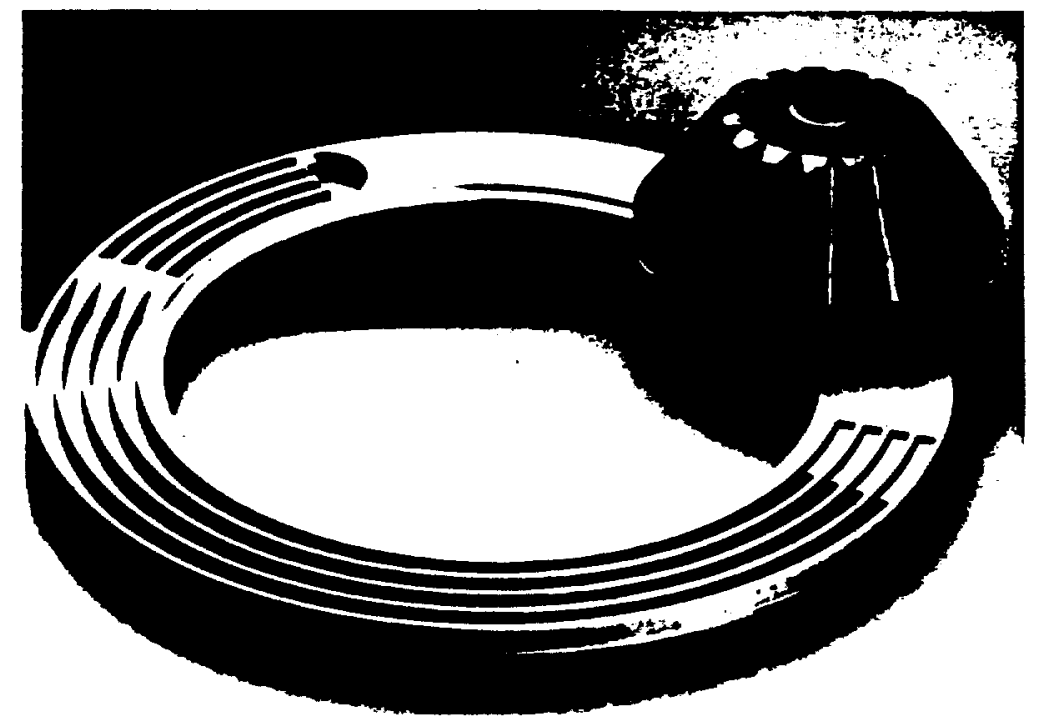

Figure 8. Superplastically formed UHCS components. The ring component $(25 \mathrm{~cm}$ in diameter) was fabricated from a UHCS $(9.3 \mathrm{Al}$ and $1.25 \mathrm{C})$ at $950^{\circ} \mathrm{C}$ in air in five minutes. The bevel gear was forged at a conventional forging rate at $650^{\circ} \mathrm{C}$ (the material is a $1.25 \%$ C UHCS).

- Economical production by bulk forming of UHCS will require three basic conditions. The applied force must be low, typically less than $35 \mathrm{MPa}$ in order to minimize die wear, the strain rate must be relatively high, $10^{-1} \mathrm{~s}^{-1}$ or faster, and the temperature of forming should not exceed $800^{\circ} \mathrm{C}$, again to save on die wear. These were the conditions set by industrial partners to a Lawrence Livermore National Laboratory government-industry consortium [24]. The three conditions were almost achieved for UHCS-high Al alloys, as shown by the results given in Fig. 9. This joint program was terminated, however, when it was discovered that the steel producer partner of the consortium could not make the UHCS-Al alloy by continuous casting because of breakout of the billet during casting; the aluminum created a brittle oxide skin which cracked during the bend portion of the vertical casting operation. 
- An example of a superplastically formed part made from a UHCS-high Al material is shown in Fig. 8. The ring component was fabricated from a UHCS-9.3Al-1.23 C at $950^{\circ} \mathrm{C}$ in air [23]. The ring, which is approximately $25 \mathrm{~cm}$ in diameter, was superplastically formed in five minutes. Commercialization of this product was intended by Sulzer Brothers of Winterthur, Switzerland, but the project was abandoned because no steel producer was prepared to make the fine-grained UHCS-high Al material. The bevel gear shown in the figure was forged at a conventional forging rate at $650^{\circ} \mathrm{C}$, and was made from an unalloyed UHCS-1.25 C material. Both components were formed close to net shape and illustrate the excellent die-fill characteristics of fine-grained UHCS.

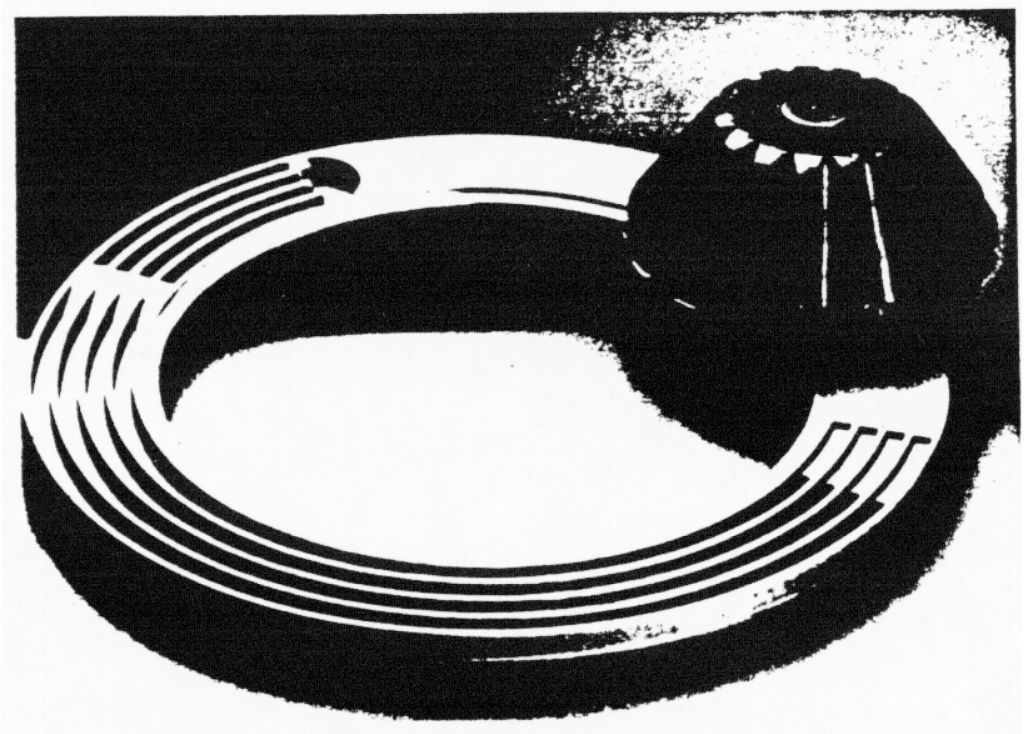

Figure 8. Superplastically formed UHCS components. The ring component $(25 \mathrm{~cm}$ in diameter) was fabricated from a UHCS $\left(9.3 \mathrm{Al}\right.$ and $1.25 \mathrm{C}$ ) at $950^{\circ} \mathrm{C}$ in air in five minutes. The bevel gear was forged at a conventional forging rate at $650^{\circ} \mathrm{C}$ (the material is a $1.25 \%$ C UHCS).

- Economical production by bulk forming of UHCS will require three basic conditions. The applied force must be low, typically less than $35 \mathrm{MPa}$ in order to minimize die wear, the strain rate must be relatively high, $10^{-1} \mathrm{~s}^{-1}$ or faster, and the temperature of forming should not exceed $800^{\circ} \mathrm{C}$, again to save on die wear. These were the conditions set by industrial partners to a Lawrence Livermore National Laboratory government-industry consortium [24]. The three conditions were almost achieved for UHCS-high Al alloys, as shown by the results given in Fig. 9. This joint program was terminated, however, when it was discovered that the steel producer partner of the consortium could not make the UHCS-Al alloy by continuous casting because of breakout of the billet during casting; the aluminum created a brittle oxide skin which cracked during the bend portion of the vertical casting operation. 


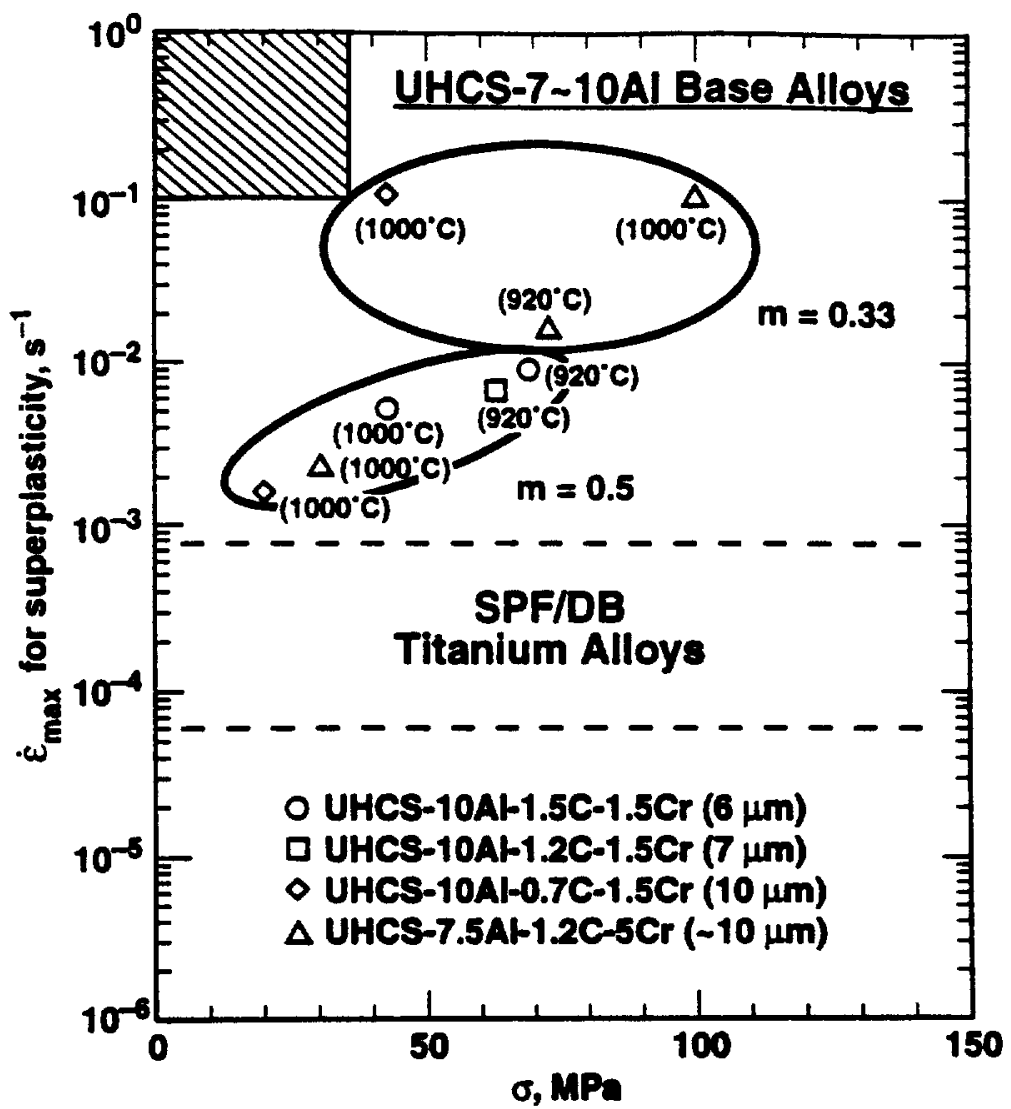

Figure 9. The maximum strain rate for superplastic flow, as a function of stress, for various UHCS-Al materials compared with the commercial goals set by the LLNL-industry consortium program (shaded area).

\section{ROOM TEMPERATURE PROPERTIES OF UHCS ALLOYS}

The UHCSs have high potential for application as structural materials. When processed to develop ultrafine ferrite grains, 0.5 to $2 \mu \mathrm{m}$, with fine spheroidized cementite particles, they are strong and ductile at room temperature. There is a big drive to create "ultrahigh strength" sheet materials for automotive applications. The primary driver is for weight reduction, which results in enhanced performance and fuel economy. In Fig. 10, the considerable increase in strength of UHCS sheet is illustrated over conventional and advanced automotive steel sheet when such steels are compared at an equivalent tensile ductility.

The current applications that use high carbon steels $(0.5$ to $1.0 \% \mathrm{C})$ are logical candidates for substitution with UHCS. For example, eutectoid composition steels $(0.8 \% \mathrm{C})$ are typically used for wires for tire reinforcement, cutting tools, and railroad rails. In these applications the UHCS will exhibit higher strengths under comparable microstructural conditions, i.e. in either spheroidized, pearlitic, bainitic, or tempered martensitic form. This is because, with a higher carbon content, the overall microstructural state can be made finer. 


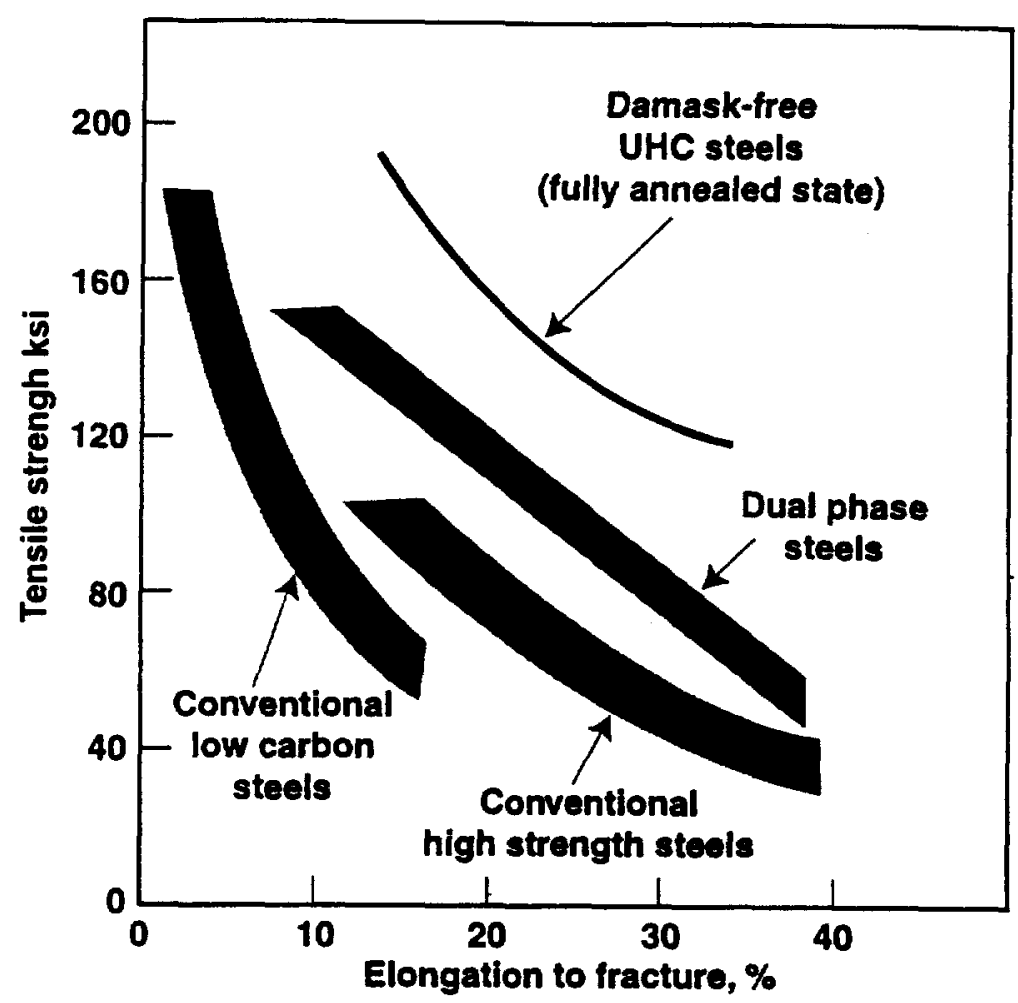

Figure 10. The considerable increase in strength of ultrahigh carbon steel sheet over conventional and advanced automotive steel sheet is illustrated when they are compared at an equivalent tensile ductility. The various strengths in the UHCS materials are achieved by different processing procedures and heat treatments (ksi x $6.895=\mathrm{MPa}$ ).

Remarkable toughness is achieved in the UHCS when tested in a fine martensitic condition [25]. An example of an austenitizing-and-quenching treatment on the room temperature mechanical properties is shown in Fig. 11. In this figure, compression stress-strain curves for a $1.3 \% \mathrm{C}$ steel in two conditions are shown with accompanying micrographs. In the first steel, designated as steel $A$, a fine-grained UHCS, such as the one shown in Fig. 4, was heat treated by quenching into water from a temperature $\left(770^{\circ} \mathrm{C}\right)$ just above the $A_{1}$ temperature. Such a heat treatment, initially producing a fine austenite grain size containing fine cementite particles, results, on quenching, in a microstructure of optically unresolvable martensite containing undissolved cementite particles (Fig. 11). This material, of $R c=67$, exhibits $10 \%$ compression ductility and a very high fracture strength of $4500 \mathrm{MPa}$. The second steel, designated as steel B, and also shown in Fig. 10, was quenched from the same low temperature of $770^{\circ} \mathrm{C}$, but in this case, it was first austenitized at $1100^{\circ} \mathrm{C}$. Such an additional step in the heat treatment results in a coarse martensite and a coarse cementite particle size. By maintaining the same carbon content in the martensite and the same volume fraction of martensite as in steel A, direct comparison can be made of the influence of fineness of the quenched structure on the properties of the two steels. The mechanical properties and microstructure of Steel B are shown in Fig. 11. This steel, which contains coarse martensite needles, has a similar hardness, $\mathrm{Rc}=67$, but a low compression fracture strength $(3000 \mathrm{MPa})$ and low ductility $(1 \%)$. Clearly, ultra- 

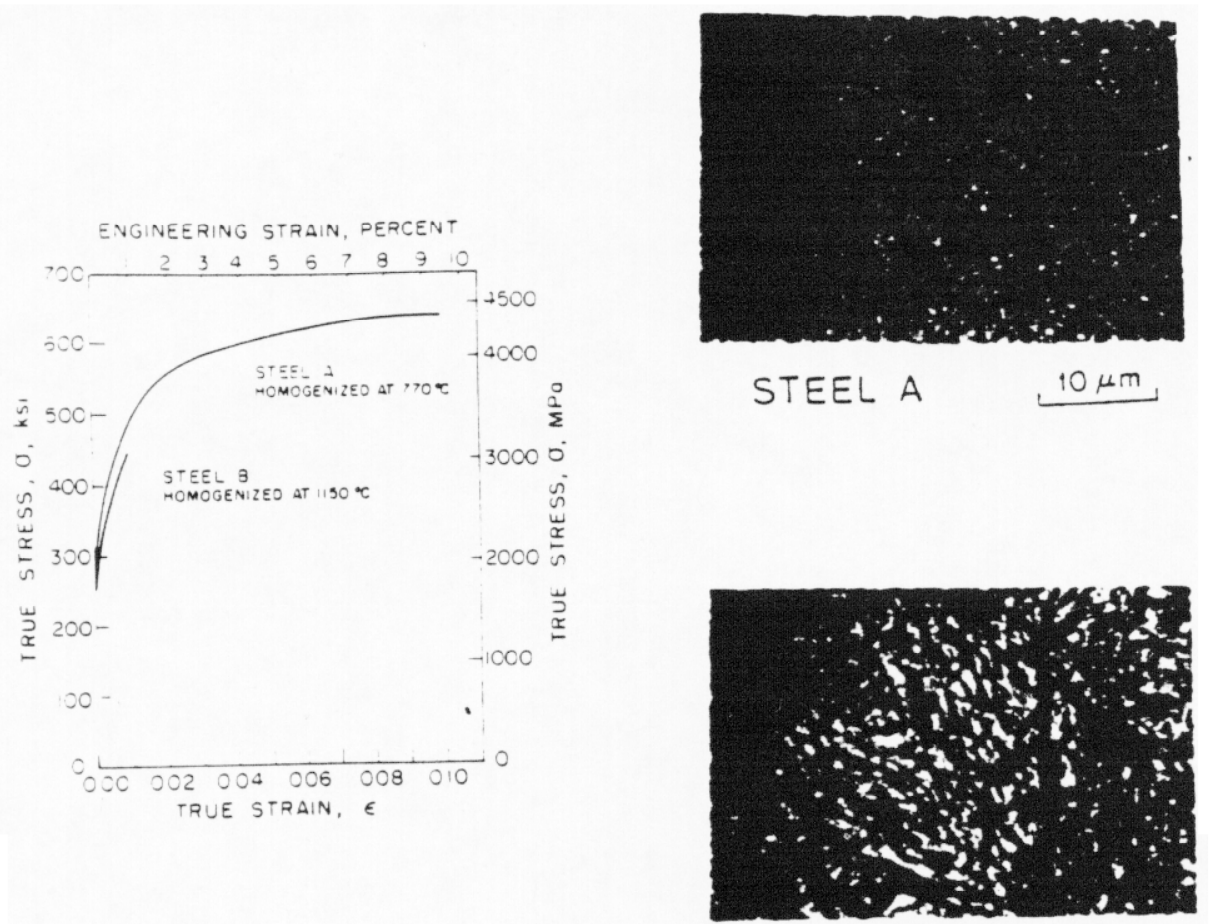

STEEL B $\quad 10 \mu \mathrm{m}$

Figure 11. The influence of prior heat treatment on UHCS quenched from $770^{\circ} \mathrm{C}$ is shown in the above figure. On the graph, the compression stress-strain curves of a $1.3 \% \mathrm{C}$ steel after two different prior heat treatments are shown with accompanying optical micrographs. The heat treatments involved, in one case heating to $770^{\circ} \mathrm{C}$ and quenching, and in the other case heating to $1150^{\circ} \mathrm{C}$, cooling to $770^{\circ} \mathrm{C}$, and then quenching.

fine-martensitic UHCS would be exceptionally suitable in wear resistant applications such as drill bits, industrial knives, and hand tools.

\section{DAMASCUS STEELS AND ULTRAHIGH CARBON STEELS}

In 1978, Sherby and Wadsworth discovered that the typical composition of carbon in the UHCS studied is essentially the same as in Damascus steel swords of ancient times, i.e., about 1.4 to $1.8 \%$ C. These weapons were renowned for their fine cutting edge and high toughness; that is, they were highly resistant to cracking. Perhaps even more important, they were famous for the incomparably beautiful surface markings which gave the weapon a mystic and spiritual feel. The method of their manufacture by blacksmiths of ancient times is believed to be a lost and forgotten art. Legends abound that Damascus steels were first developed at the lost continent of Atlantis, that they were brought to India when Atlantis sank, that they had special healing powers, and that they were used by Alexander the Great in his conquest of the civilized world. These fascinating tales led us to investigate the history of Damascus steel making. In the process, an effort was made to reproduce such markings on UHCS materials, and after success was achieved $[26,27]$, the published procedure was described as the modern rediscovery of Damascus steel making.

An example of a Damascus steel sword (a Persian scimitar) is shown in Fig. 12. The special surface pattern is a swirly distribution of the proeutectoid carbides (the white areas) 

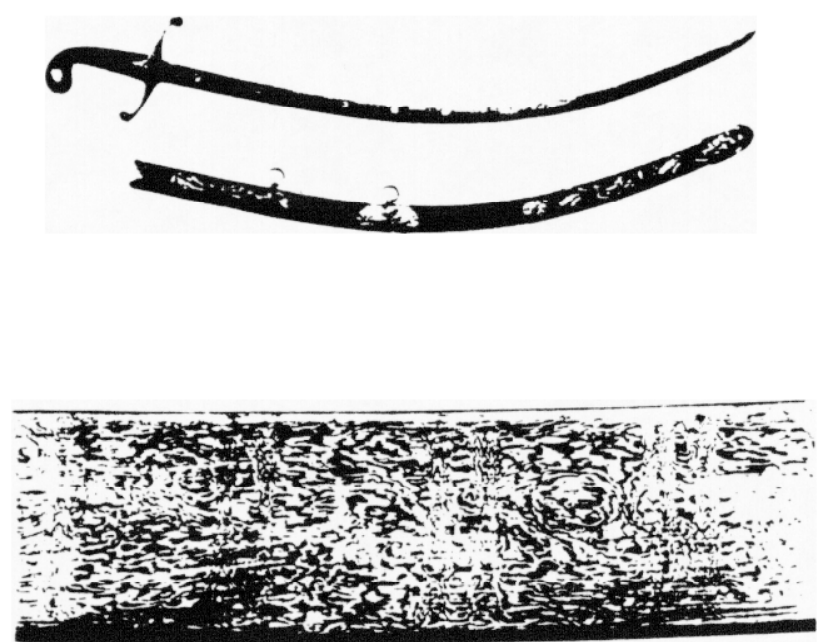

Figure 12. Persian scimitar dating from the 17th century or later in the Metropolitan Museum of Art, New York. The white areas are from aggregations of coarse cementite particles. The local effects of forging are recognizable as vertical arrays in this unusual form of a damask known as Mohammed's ladder.

achieved by a complex forging procedure. These white regions are different from, but related to, the iron carbide network shown in Fig. 2 . The vertical arrays, known as "Mohammed's ladder", arise from the different directions of upset forging.

It is believed that the Damascus steel was made in India where it was known as wootz. It was widely traded in the form of castings, or cakes, that were about the size of hockey pucks. The best blades are believed to have been forged in Persia from Indian wootz, which was also used to make shields and armor. These steels were known in the middle ages in Russia where they were called "bulat" steels. In Persia, they were known as "pouhad Janherder".

Figure 13 illustrates a drawing of King Puru of India greeting Alexander the Great (about $330 \mathrm{BC}$ ). This painting is in the guest house of the largest R\&D steel laboratory in the world, the Steel Authority of India, in Ranchi (with a staff of 1200 research scientists and support personnel). After King Puru was defeated by Alexander the Great in battle, (as shown in the painting), the King gave, as a token of respect, his sword to Alexander, and behind the King, his aide is carrying an additional gift, a gold container within which is a cake of Indian wootz. At the time, this steel was more prized than gold!! In a more recent period, the Russian poet, Alexander Pushkin immortalized "bulat" with a similar comparison, when he wrote, in 1830, the following poem [28]:

All is mine, said gold

All is mine, said bulat

All I can buy, said gold

All I will take, said bulat

The exact procedures used by the ancient blacksmiths in making the surface markings on genuine Damascus steel swords (it is termed 'genuine' because it is made from a single 


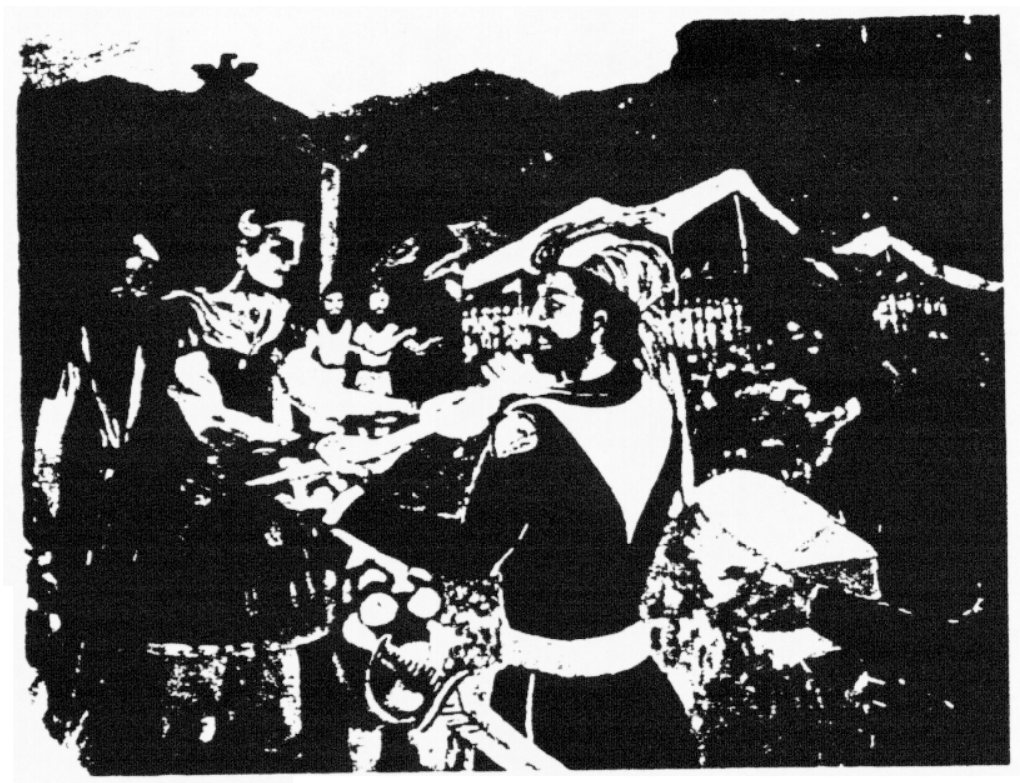

Figure 13. A painting from a mural in Ranchi, India, depicting King Puru of India presenting gifts to Alexander the Great. One gift is an Indian wootz sample contained within the gold box.

ultrahigh carbon composition casting) have been the source of much speculation. When procedures are described, they are usually given in vague terms, with no precise descriptions of temperature of forging, of the cooling rate prior to and after forging, or of the degree of deformation given at each step. In 1979 [29], a specific procedure was proposed which may have been used by the ancient blacksmiths and has become known as the "Wadsworth-Sherby" method [30]. The procedure utilized is a rolling process involving three key steps.

First, the wootz (in this case, an UHCS containing over $1.5 \% \mathrm{C}$ ) is heated to near its incipient melting point (a white heat $-1200^{\circ} \mathrm{C}$ ) to develop coarse iron grains. Second, the wootz is cooled very slowly, over a period of several hours, to form a thick continuous network of iron carbide at the boundaries of these coarse iron grains. At this point, surface markings are visible to the naked eye consisting of spherical grains with a thick border of iron carbide (Fig. 3). Third, the wootz is heated to a color between blood red and cherry (i.e. about 650 to $750^{\circ} \mathrm{C}$ ), a temperature at which the iron carbide network will not dissolve, and the wootz is then mechanically worked extensively to break the network into individual, coarse iron carbide spherical or elongated particles. The network is now no longer continuous, but remains visible as a layered structure, and is very appealing to the naked eye.

Photomicrographs of a UHCS-1.8 C material, processed by the "Wadsworth-Sherby" method, are shown in Fig. 14 [31]. The low-magnification, optical photomicrograph on the left shows the proeutectoid carbide network with coarse dimensions of about $0.2 \mathrm{~mm}$ by $2 \mathrm{~mm}$. It appears to be continuous but, in fact, is not; rather, it consists of broken-up carbides. The background matrix within and adjoining the carbide network is dark upon etching and unresovable at low magnification. When the carbide network and the matrix are viewed at high magnification, with the scanning electron microscope, the structure is seen to consist of fine iron grains with fine spheroidized carbides (depending on the final temperature of mechanical working, the matrix can be fine pearlite). The matrix is much 


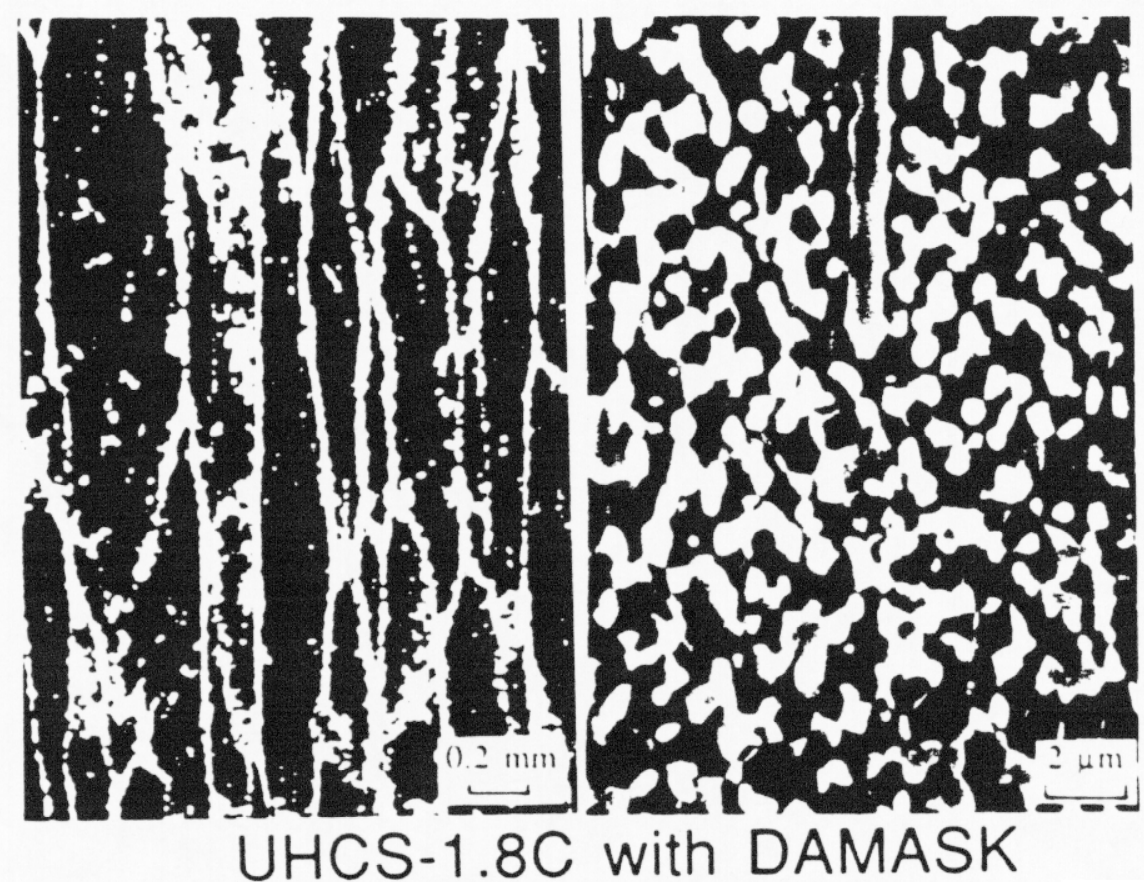

Figure 14. Photomicrographs of a UHCS-1.8 C material, processed by the WadsworthSherby recipe. The photomicrograph on the left shows the proeutectoid carbide network with coarse dimensions of about $0.2 \mathrm{~mm} \times 2 \mathrm{~mm}$.

like the TEM photo shown in Fig. 4. A large elongated carbide, which is part of the discontinuous network of carbides, is seen in the top center of the photomicrograph.

Small changes in the processing procedure for making visible damasks can lead to woodlike patterns in the UHCS-1.8 C material. Figure 15 is illustrative of this pattern. Photomicrographs are shown at three different magnifications. On the left is a low magnification photo showing the wood-like pattern. In the top right, at a higher magnification, the dark etching bands are the broken up proeutectoid carbides. The highest magnification photomicrograph, lower right, show the bands of alternating coarse and fine carbides.

In order to evaluate the potential for genuine Damascus steels with markings to exhibit superplasticity, tension tests were performed at elevated temperature on the UHCS-1.8\% C material containing the visible damask shown in Fig. 14. The material composition was $1.8 \% \mathrm{C}, 1.6 \% \mathrm{Al}, 1.5 \% \mathrm{Cr}, 0.5 \% \mathrm{Mn}$ and balance iron. The flow stress-strain rate response of the UHCS material at $750^{\circ} \mathrm{C}$ is shown in Fig. 16. The material was found to be superplastic, with the slope of the stress-strain rate curve showing a strain-rate sensitivity exponent of 0.43 . In the same figure, a sample tested at a strain rate of two percent per minute is shown to exhibit an elongation of $450 \%$ These results suggest that the ancient Damascus steel weapons could have exhibited superplastic characteristics near the $\mathrm{A}_{1}$ transformation temperature. 

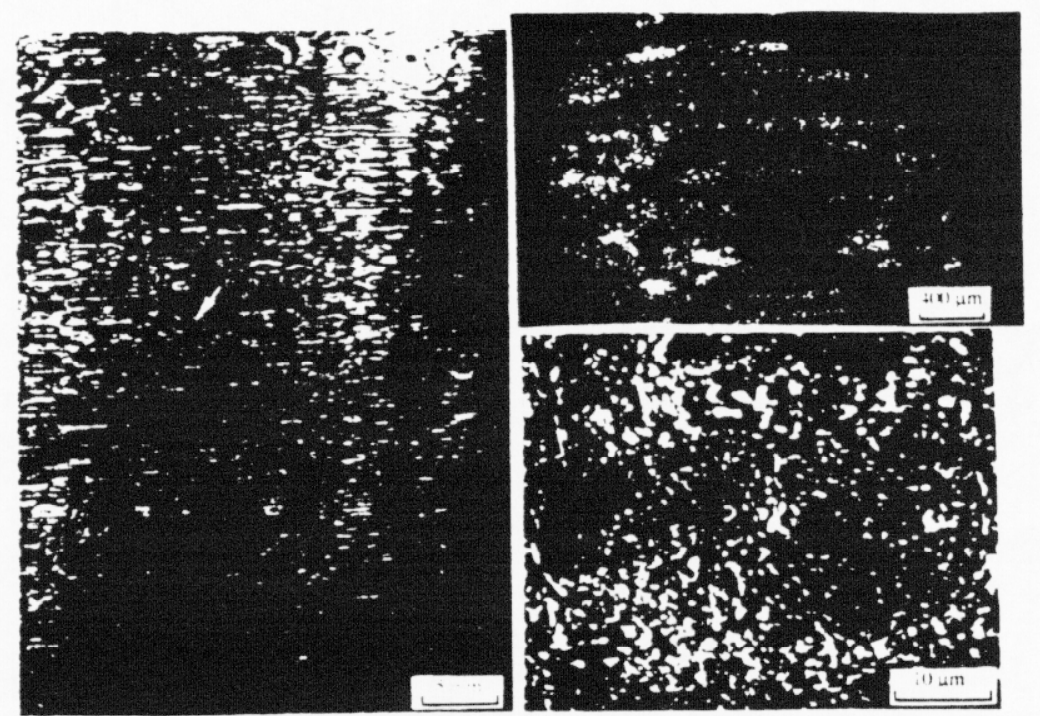

LHCS - $1.8 \mathrm{C}$ with Wood-like DAMASK

Figure 15. Damask on a UHCS-1.8 C material processed by rolling to obtain a wood-like structure. Three magnifications are shown illustrating the severe break-up of the proeutectoid carbides in band-like regions.

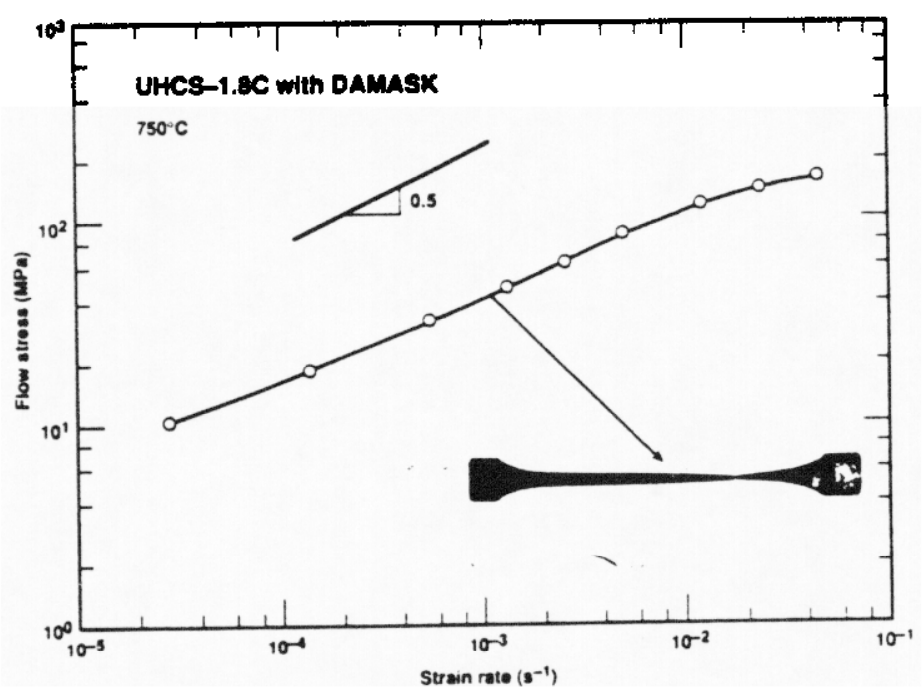

Figure 16. The flow stress-strain rate response of the UHCS material with visible damask at $750^{\circ} \mathrm{C}$. The slope of the stress-strain rate curve shows a superplastic strain-rate sensitivity exponent of 0.43 . The sample was tested at a strain-rate of $2 \%$ per minute to an elongation of $450 \%$. 
The room temperature mechanical properties of the UHCS material depicted in Fig. 14 exhibited a yield strength of $920 \mathrm{MPa}$, an ultimate strength of $1,145 \mathrm{MPa}$, and a total elongation of $12 \%$. This is a remarkable combination of strength and ductility and confirms the general statements made about the malleability of ancient Damascus steels. Recent studies on the same damask-containing material but with a pearlitic matrix have shown even higher yield strengths with good ductility [32].

\section{CONCLUSIONS}

Ultrahigh carbon steels can be processed to achieve ultra-fine structures resulting in outstanding properties at high and low temperature. They exhibit outstanding superplastic properties at elevated temperature, and are strong and ductile at low temperature. Very high hardnesses with good toughness can be achieved by heat treatment with ultrafine martensitic structures. These hypereutectoid steels are ideal for applications where high carbon steels are currently used since higher strengths and wear resistance are obtained than with the 0.5 to $0.8 \% \mathrm{C}$ materials. The role of alloy additions with silicon and aluminum is worthy of additional studies in further enhancing the mechanical properties of UHCS.

\section{ACKNOWLEDGMENTS}

The authors thank many former colleagues at Stanford University, and present colleagues at the Lawrence Livermore National Laboratory, for work quoted in this paper. Special thanks are given to Dr. H.C. Tsai who helped with the more recent experiments on ultrahigh carbon steel containing damask surfaces and to Dr. S. Banerjee, Director of the R\&D Center for the Steel Authority of India for the description of the King PuruAlexander the Great encounter. One of the authors, O.D. Sherby, acknowledges support from Professor E.S. Kayali, Chairman of the Ninth International Metallurgy and Materials Congress. Work was performed under the auspices of the U.S. Department of Energy by the Lawrence Livermore National Laboratory under contract No. W-7405-Eng-48.

\section{REFERENCES}

1. H.M. Howe, "The Metallurgy of Steel," Vol. I, 2nd Edition, The Scientific Publishing Company, New York, NY (1891), p. 16.

2. H. Carpenter and J.M. Robertson, "Metals", Vol II, Oxford University Press, London, (1939), p. 1081.

3. A.H. Cottrell, "An Introduction to Metallurgy," Edward Amold (Publishers) Ltd., London, (1967), p. 511.

4. M.F. Ashby and D.R.H. Jones, "Engineering Materials", Vol. 2, Pergamon Press, (1986), pp. 109, 112.

5. C.K. Syn, D.R. Lesuer, and O.D. Sherby, "Influence of Microstructure on Tensile Properties of Spheroidized Ultrahigh Carbon (1.8\%C) Steel," Metall. Trans., 25A, pp. 1481-1493.

6. O.D. Sherby, C.M. Young, B. Walser, and E.M. Cady, Jr., "Superplastic Ultrahigh Carbon Steel," United States Patent \#3,951,697, April 20, 1976.

7. O.D. Sherby, T. Oyama, D.W. Kum, B. Walser, and J. Wadsworth, "Ultrahigh Carbon Steels," J. Metals, 37, (6), (1985), pp. 50-56.

8. D.R. Lesuer, C.K. Syn, A. Goldberg, J. Wadsworth, and O.D. Sherby, "The Case for Ultrahigh Carbon Steels as Structural Materials," J. Metals, 45, (1993), pp. 40 46. 
9. E.S. Kayali, H. Sunada, T. Oyama, J. Wadsworth, and O.D. Sherby, "The Development of Fine Structure Superplasticity in Cast Ultrahigh Carbon Steels Through Thermal Cycling," J. Mater. Sci., 14, (1979), pp. 2688-2692.

10. T. Oyama, J. Wadsworth, M. Korchynsky, and O.D. Sherby, "Influence of Dilute Alloying Additions on the Superplastic Properties of Ultrahigh Carbon Steels," in Strength of Metals and Alloys, (Eds. P. Haasen, V. Gerold, and G. Kostorz), Vol. 1, Pergamon Press, (1979), pp. 381-386.

11. J. Wadsworth and O.D. Sherby, "Influence of Nickel and Vanadium on Superplasticity in Ultrahigh Carbon Steels," J. Mech. Work. Tech., 2, (1978), pp. 53-66.

12. J. Wadsworth and O.D. Sherby, "Influence of Chromium on Superplasticity in Ultra-High Carbon Steels," J. Mater. Sci., 13, (1978), pp. 2645-2649.

13. J. Wadsworth, J.H. Lin, and O.D. Sherby, "Superplasticity in a Tool Steel," Metals. Technol., 8, (1981), pp. 190-193.

14. E.S. Kayali, PhD. Dissertation, Dept. of Materials Science and Engineering, Stanford University, Stanford, CA, June, 1976.

15. B. Walser, E.S. Kayali, and O.D. Sherby, "Warm Working and Superplasticity in Plain Ultrahigh Carbon Steels," 4th International Conference on the Strength of Metals and Alloys, Nancy, France, (1976), Volume 1, pp. 456-460.

16. O.D. Sherby and T. Oyama, "Ultrahigh Carbon Steel Alloy and Processing Thereof," United States Patent No. 4,533,390, August 6, 1985.

17. O.D. Sherby, D.W. Kum, T. Oyama, and J. Wadsworth, "Ultrahigh Carbon Steels Containing Aluminum," United States Patent 4,769,214, September 6, 1988.

18. O.D. Sherby, D.R. Lesuer, and C.K. Syn, "Superplastic Behavior of Ultrahigh Carbon Steel Containing Aluminum," Progress in Advanced Materials and Mechanics, Beijing, China, (1996), Proceedings of the International Conference on Advanced Materials, Volume 2, Chinese Journal of Mechanics Press, Beijing, China, (1996), pp. 77-82.

19. E.M. Taleff, M. Nagao, K. Higashi, and O.D. Sherby, "High-Strain-Rate Superplasticity in Ultrahigh-Carbon Steel Containing 10 wt.\% Al (UHCS-10Al)," Scripta Mater., 34, (1996), pp. 1919-1923.

20. H. Fukuyo, H.C Tsai, T. Oyama, and O.D. Sherby, "Superplasticity and Newtonian-viscous Flow in Fine-grained Classs I Solid Solution Alloys," ISIJ International, 31, (1991), pp. 76-85.

21. A. Ball and M.M. Hutchinson, J. Mater. Sci. 3, (1969), p. 1.

22. O.D. Sherby, T.G. Nieh, and J. Wadsworth, "Overview on Superplasticity Research on Small Grained Materials," in Materials Science Forum, Vols. 170-172, p. 13, (Ed. T.G. Langdon), Trans Tech. Publications, Switzerland, (1994).

23. J. Wittenauer, P. Schepp, and B. Walser, "Application of Superplastic UHC Steel for Isothermal Forging of Machine Components," Superplasticity and Superplastic Eorming, (Eds. C.H. Hamilton and N.E. Paton), TMS, Warrendale, PA, (1988), pp. 507-511.

24. U.S. Dept. of Energy, Office of Industrial Processes, Steel and Aluminum Energy Conservation and Technology Competitiveness Act of 1988, FY 1992 and 1993 Annual Reports, U.S. Dept. of Commerce, National Technical Information Service, Springfield, VA.

25. H. Sunada, J. Wadsworth, J. Lin, and O.D. Sherby, "Mechanical Properties and Microstructure of Heat-Treated Ultrahigh Carbon Steels," Mater. Sci. Eng., 38, (1979), pp. 35-40.

26. J. Wadsworth and O.D. Sherby, "On the Bulat - Damascus Steels Revisited," Prog. Mater. Sci., 25, 1980, pp. 35-68.

27. J.Wadsworth and O.D. Sherby, "Damascus Steels," Scientific American, 252, (2), (1985), pp. 112-120.

28. A.C. Pushkin, Vol 1, Udozestvennia Literaturea, Moscow, (1978), p. 229. 
29. J. Wadsworth and O.D. Sherby, "On the Bulat (Damascus Steels)," Annual Bulletin of the Metals Museum, The Japan Institute of Metals, Sendai 980, Japan, 4, (1979), pp. 7-23.

30. J. Wadsworth and O.D. Sherby, "Comments on 'Damascus Steel, Part III: The Wadsworth-Sherby Mechanism' by Verhoeven et al," Materials Characterization, 28, (2), (1992), pp. 165-172.

31. O.D. Sherby and J. Wadsworth, "Damascus Steel and Superplasticity - Part I Background, Superplasticity, and Genuine Damascus Steel", SAMPE Journal, $\mathbf{3 1}$, (1995), pp. 10-17.

32. E. Taleff, C. Syn, D. Lesuer, and O.D. Sherby, "Mechanical Behavior of a Hypereutectoid Steel Exhibiting a Damask Surface Pattern," in Thermal-Mechanical Processing and Mechanical Properties of Hypereutectoid Steels and Cast Irons, Indianapolis, Indiana, (Eds. D.L Lesuer, C. Syn, and O.D. Sherby), TMS publication, Warrendale, PA (to be published - 1997). 


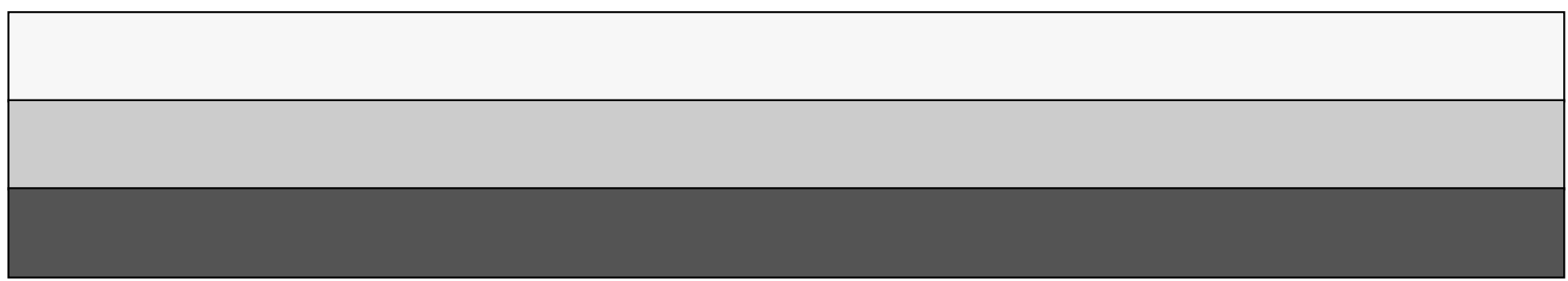

